\title{
The Interaction of Profitability with Solvency: A Simple Model of a Bank
}

Srđan Marinković*

Abstract:

This paper develops a simple deterministic model to analyze how the profitability of bank operations infuences the solvency of a banking firm. The results imply that the solvency ratio is directly related to the net interest margin (the "bread and butter" of bank profitability) and inversely related to the liquidity ratio. This model has several implications on the design of banking regulations: i) profitability has to be treated as "marginal" solvency, ii) a profitable bank can operate sustainably even with a low level of equity capital; iii) the supervisory framework has to be able to recognize any measure of earnings level, its trends, stability and quality; and finally iv) the frequency of audit trials has to be as high as possible.

Keywords: Profitability, solvency, bank model, net interest margin.

JEL: G21; G18; C51;

DOI: $10.2478 / \mathrm{v} 10033-009-0016-1$

\section{Introduction}

The main issue to be addressed here is how the profitability of banking operations contributes to bank solvency, i.e. capital adequacy. This issue has some regulatory implications, which shall also be discussed. The nexus of relations between the level of equity (capital, or equity capital, which is the term that will be used in this paper) and the profitability of a financial institution is well above the interest of this paper. It could be a far more complicated issue. For example, having ignored the regulatory pressure on the financial industry to sustain a prudently sufficient level of capital, there is the desire of shareholders to keep capital as low as possible for a given level of return, so as to maximize the return on capital. The more capital banks have to hold, the more difficult it is to generate the return required to shareholders. This paper does not seek to address this manner of influence, i.e. the needed level of capital to create a target level of profitability. On the contrary, the issue here is how deterministic (or stohastic) profitability influences the economic and regulatory capital of financial institutions.
At this point a reader will gain from some definitions. Economic (or risk) capital is taken here as (Merton and Perold, 1993, p. 17) "the smallest amount that can be invested to insure the value of the firm's net assets against a loss in value relative to the risk-free investment of those net assets." Here regulatory capital refers to regulatory constraint, i.e. the minimum capital requirements which banks are required to hold. How much risk capital does a financial institution need? It is obvious that it depends on the earnings it creates. Within a simple deterministic approach, if earnings are positive a bank does not need capital at all. But in a more realistic, stochastic (or uncertain) world, it is clear that more volatile earnings come with higher capital needs. To state it in a more formal way (Matten, 1996, p. 104) the relationship between earnings-at-risk and risk capital is as follows: risk or economic capital is earnings-at-risk

\section{*Srđan Marinković}

Faculty of Economics, University of Niš

e-mail: srdjan@eknfak.ni.ac.yu; srdjan.m@neobee.net; 
divided by risk-free rate. Hence, the question is how much capital would be needed to ensure that the probable level of volatility is offset by risk-free earnings, or how much capital, invested at a risk-free rate, generates a return equal to earnings-at-risk. From this relation it becomes clear that the amount of capital needed to protect bank debtholders (i.e. creditors and depositors) is closely related to bank earnings, depending on both its size and variability, or risk.

\section{The role of equity capital in a profitable bank}

The principle of profitability and principle of solvency are closely related to each other. Assuming that all earnings (net income after tax, or profit; these three notions here shall all be used interchangeably) are retained, profitability becomes the main source of equity growth, and hence the way for a bank to stay solvent at all times. Therefore, profit becomes "marginal" equity. Namely, by making a net income a bank increases its equity capital, the same way that by making loss equity capital decreases for the amount of loss, ceteris paribus.

Other than this direct "funding" relation between profitability and solvency, there are also a number of other similarities between the two concepts. The problems that are involved in the calculations of economic (real) profitability are an inherent part of the calculation of economic capital (or solvency) as well, e.g. information issues related to the market (economic) value of assets, asset quality measures, loan loss provisions etc. While normal or anticipated losses are covered by regular revenues, the role of capital in a bank is to act as a buffer against future, unidentified, even relatively improbable losses, whilst still leaving the bank able to operate at the same level of capacity (Matten, 1996, p. 9). Hence, the capital has a "buffer" role, and it is a "margin for error" because the level of capital has to be somewhat larger than simply a cushion against "normal" losses.

Bank capital has at least two roles: a) it gives the right to equity holders to manage the bank, but also b) creates a kind of buffer or guarantee available to bank creditors in case of bankruptcy (extraordinary loss). When a bank operates profitably, the purpose (even the rationale) of $a$ priori imposed regulatory capital requirements vanishes concerning the second role of capital. Then equity capital retains only the role of representing "a key for distributing net income among shareholders" (Krstić, 1996, p. 57). "Experience suggests only the observation - simple but sound - that a well-managed and profitable bank can get along with an extremely low capital ratio, whereas no amount of capital will suffice to guarantee the solvency either of a poorly managed bank that likes to place bets ... that is forced to operate under rules or in an environment that render it unviable..." (cf. Stigum and Branch, 1983, p. 181) and further on "...the answer to the question of bank capital adequacy is to argue that what should really count is not the absolute ratio of a bank's capital to its risk assets, but rather the size and constituency of its earning. If a bank's earnings grow on average, and if it is consistently adding to its capital through retained earnings, then all the functions of capital are fulfilled, and the bank therefore must be judged to have adequate capital." (Ibidem, p. 182-183)

Referencing the quoted passage from Stigum and Branch (1983, p. 181), Cirović (1995, p. 243) argues that "this conception [is] of course partly correct, in the sense that bank equity represents a stock concept, while as a point of necessity for being solvent at all times the "concept of flows" is most important. This concept is a reminder that a bank has to operate with high enough revenues so as to be able to cover all its expenses. If it is assumed that a bank always makes enough revenue to cover all of its expenses, than equity capital would not be a necessary "buffer" for losses. In that case the only role capital is to play is to be the key for distributing net income amongst shareholders. However, the real rationale for holding equity capital has to be in case of unforseen and extraordinary losses, in which case it presents ex ante allowance aimed to cover losses, and hence to help the bank stay solvent."

Empirical research has also pointed out that profitability is negatively correlated with leverage, i.e. positively correlated with solvency ratios (Rajan and Zingales, 1995, p. 1457). The authors show that "[i]f in the short run, dividends and investments are fixed, and if debt financing is the dominant mode of external financing, then changes in profitability will be negatively correlated with changes in leverage." Banking is rightly an industry where debt financing is the dominant mode of external financing. The assumption about fixed dividends supports the view, presented here, that solvency is "safe" as long as the bank operates profitably. This is not unrealistic. For example, Myers (2003, p. 151.) states that "firms have well-defined, sticky policies that regulate dividends per share." Indeed, in reality a bank's major source of equity capital is its flow of net income after dividends or its long-term profitability. Data colected on US banks show that on average the ratio of retained 
earnings to total assets was 0.28 percent for the period from 1995 to 1999. Over a fifteen year long period, it was only on account of this source that banks were able to raise enough equity capital to raise their assets ratio to five percent. Moreover, retained earnings present the most stable source of equity capital (Sinkey, 2002, Table $9-4$, p. 285). On average, the equity capital of US banks is up to four fifths financed with retained earnings. This is taken as evidence here in support of the pecking order hypothesis. The pecking order model predicts that firms rank financing sources by their sensitivity to asymmetric information, the order of which is internal financing (i.e. retained earnings), debt, and external equity sources (cf. Myers and Majluf, 1984, or Myers, 1984).

In emerging market banks rely even more on retained earnings as a source of equity capital. In Serbian banking, the figures point to a somewhat different position. The Serbian banking industry is not comparable to developed countries due to several factors. First, a huge proportion of banks are newly established. Their short period of existence has constrained the banks from reporting a significant amount of retained earnings, even those who have operated profitably since their establishment. Second, some of the banks whose origin can be traced back to the former socialist period are burdened with inherited losses, so that new banks to the market that have taken over these older banks have assumed negative retained earnings. On average (weighted), retained earnings take up 16.86 percent of all equity resources. The figure is even smaller for the unweighted average (10.29). The figures are this small because in summing up individual bank data positive accumulated earnings are offset by negative earnings or accumulated losses. But when analyzing profitable and non-profitable banks separately the former group (sample) has 27.15 percent of its total equity capital generated by retained earnings, while for the latter the figure is negative 16.20 percent (2007). Keeping in mind the short existences of the majority of banks in the industry, the figures above are still in line with the theory and other countries' empirical evidence.

\section{The formal model}

The solvency condition is as follows (Jović, 1990, p. 245):

$$
N W=A-L>0 \Leftrightarrow A>L
$$

Where NW, $A$ and $L$ stand for Net Worth, Assets and Liabilities, respectively. The profit equation is:

$$
\pi_{T-t}=\Delta A_{T-t}-\Delta L_{T-t}=A_{r}\left(e^{r_{a} T-t}-1\right)-L\left(e^{r_{l} T-t}-1\right)
$$

Where $e^{r_{a}}$ is the continuously compounded (logarithmic) rate of return on earning assets, $e^{r_{l}}$ the continuously compounded cost rate of debt funds, $r_{a}$ the annual rate of return on earning assets, and $r_{l}$ the annual cost rate of debt.

Equation (2) has the following economic rationale. Net profit generated at time interval $T-t$ is the difference between growth of assets and liability values. The value of a bank's assets increases at the rate of return while the value of liabilities (debt) increases at the cost rate.

Assumption 1: The only source of income is interest income, and the only source of expenses is interest expenses. Other sources of bank revenue, e.g. noninterest income, is ignored, as well as noninterest expenses. Therefore, only the balance sheet items matter.

To keep the subsequent analysis as simple as possible it will be supposed here that the rate of return and the cost rate are certain. This allows for the development of a simple deterministic framework by assuming the following:

Assumption 2: Rates of return on assets and cost rate of liabilities are represented by their means, i.e. expected value.

\subsection{Liquidity constraints}

Note that the profit equation (2) is expressed in terms of earning assets. The empirical fact is that banks seeking to maximize their profitability are constrained by liquidity requirements. Namely, in order to operate their ongoing concern is to meet their financial obligations on time, for the regular concern is to hold some cash or cash-like holdings. Those holdings are nonearning assets known as liquidity reserves. If for the sake of simplicity it is assumed that those assets produce no income, the total assets could be decomposed into earning assets $\left(A_{r}\right)$ and nonearning assets, or liquidity reserves $\left(A_{1}\right)$. Also, for the sake of simplicity this approach will ignore that liquidity reserves could change over time, and assume that the ratio of liquidity reserves is constant over time.

\section{Assumption 3: Liquidity ratio is constant over time.}

$$
A=A_{l}+A_{r}
$$

If, instead, the above formula (3) is expressed solely in terms of earning assets rather than both earning assets and liquidity reserves, another ratio must be introduced, i.e. the liquidity ratio (I). This ratio is given by dividing 
liquidity reserves by total assets. After some simple algebra the following is arrived at:

$$
l=\frac{A_{l}}{A}=\frac{A-A_{r}}{A}=1-\frac{A_{r}}{A}
$$

Therefore:

$$
A_{r}=A(1-l)
$$

By expression (5) the relation between total assets and earning assets is defined using the liquidity ratio. Yet another formulation expresses the bank profit not in the form of earning assets $A_{r}$ but in the form of total assets $A$. From (2), this version yields:

$$
\pi_{T-t}=A_{t}(1-l)\left[\left(e^{r_{a} T-t}-1\right)-L_{t}\left(e^{r_{l} T-t}-1\right)\right]
$$

The following are expressions for the future value of financial liability or debt $\left(L_{t+1}\right)$ and the future value of assets $\left(A_{t+1}\right)$, respectively, for a discrete period of time equalling one time interval.

$$
\begin{aligned}
& L_{t+1}=L_{t}+\Delta L_{t+1, t}=L_{t} e^{r_{l} T-t} \\
& A_{t+1}=A_{t}+\Delta A_{t+1, t}
\end{aligned}
$$

According to the above (7b) the terminal value of total assets can be decomposed into its components, so that it is calculated now:

$$
A_{t+1}=\left(A_{l, t}+A_{r, t}\right)+\Delta A_{r, t}=A_{l, t}+A_{r, t} e^{r_{a} T-t}
$$

Provided the liquidity ratio is constant over time it follows that the future value of assets depends solely on changes to earning assets, as shown in equation (8).

\subsection{Net worth equation}

The question remains whether such a bank will be solvent at a point in the future $T$. The answer will be given through composing a net worth equation. As net profit (earnings) represents one of the most important sources for growth of equity capital, the relation between profitability and solvency is obvious. In order for the model to be more realistic, it will be assumed that the entire profit of the current year does not go toward general reserves, and a part of the earnings are distributed to shareholders. The ratio between dividends and total net profit is the dividend payout ratio, noted as $\alpha$, such that it satisfies the following expressions: $\Delta A_{T-t}-\Delta L_{T-t}=\pi_{T-t}(1-\alpha) ; \quad$ and $\quad(\alpha \geq 0)$, where $(1-\alpha)$ is by definition the retention ratio. The higher the retention ratio (i.e. the lower the dividend payout ratio), the higher the net worth and vice versa.
In order to translate the profit equation into a net worth equation an additional assumption is needed.

Assumption 4: No external funds are aquired in the period, so that the only way for assets to grow is to invest $A_{T}$ into profitable opportunities.

This leads to the following definition of term value of bank net worth, subject to the above restriction (assumption 4):

$$
\begin{aligned}
& N W_{T}=A_{T}-L_{T}=(1-\alpha)\left[A_{t} e^{r_{a} T-t}(1-l)-L_{t} e^{r_{l} T-t}\right] \geq 0 \\
& \Leftrightarrow r_{a}(1-l) \geq r_{l}
\end{aligned}
$$

where:

$$
\text { i) } e^{r_{a} T-t}(1-l) \text { is the rate of return on total assets }
$$

over the period $T-t$;

Proposition 1: If it is supposed that a bank has an equal amount of assets and liabilities at moment t, i.e. a bank operates at zero solvency, $A_{t}-L_{t}=0$, the bank will stay solvent if only the following condition is satisfied:

$$
\frac{r_{a}}{r_{l}} \geq \frac{1}{(1-l)}
$$

This shows that, provided the assumptions are satisfied, a bank will remain solvent if only the rate of return on assets are above the cost rate of debt funds for an amount higher than $\frac{1}{(1-l)}$.

It follows from here that liquidity ratio influences adversely the level of profitability, and solvency as well. Also from condition (10) it follows that bank profitability, as well as its solvency, will depend on the difference between the rate of return on assets and the cost rate of debt funds used to finance the assets.

\subsection{Net Interest Margin}

Note that bank profit is expressed solely through the difference between interest income and interest expenses. This is derived from assumption (2) i.e. that income sources other than interest income are ignored.

The bank interest margin, or net interest margin as it is commonly referred to, is usually defined as the difference between interest revenue and interest expenses expressed as the percentage of average earning assets (cf. Sinkey, 2002, p. 119). Interest spread, on the other hand, is the difference between the yield rate on average interest earning assets and the cost rate on the interest bearing fund, with both elements expressed in percentage terms. 
Clearly, the bank interest margin and spread need not be identical unless there are zero non-interest bearing funds. However, abstracting from the abovementioned difference caused by non-interest bearing funds, those two bank efficiency measures could be considered equal.

It is well known that the bank interest margin is an important component of bank profitability. An adequate interest margin should generate sufficient income to increase the capital base as risk exposure increases (cf. Angbazo, 1997, p. 56).

Net interest margin can be written as the following identity:

$$
N I M=\frac{1}{A_{r}}\left[A_{r}\left(e^{r_{a}}-1\right)-L\left(e^{r_{l}}-1\right)\right]
$$

or:

$$
N I M=\left(e^{r_{a}}-1\right)-\frac{L}{A_{r}}\left(e^{r_{l}}-1\right)
$$

Combining (5) and (12) implies that:

$$
N I M=\left(e^{r_{a}}-1\right)-\frac{L}{A(1-l)}\left(e^{r_{l}}-1\right)
$$

One can further rearrange (13) introducing an explicit expression for the solvency ratio, whereby the solvency ratio or capital adequacy (not adjusted for risk) is written as:

$$
\sigma=\frac{N W}{A}=\frac{A-L}{A}=1-\frac{L}{A}
$$

Substituting equation (14) into equation (13) leads to the following definition of net interest margin (NIM):

$$
N I M=\left(e^{r_{a}}-1\right)-\frac{1-\sigma}{1-l}\left(e^{r_{l}}-1\right)
$$

From the statement above (15) another proposition can be derived:

Proposition 2: Solvency is a positive function of net interest margin (NIM).

Namely, by further rearranging the equation (15) the following is arrived at:

$$
\frac{1-\sigma}{1-l}\left(e^{r_{l}}-1\right)=\left(e^{r_{a}}-1\right)-N I M
$$

It must also be the case that:

$$
\frac{1-\sigma}{1-l}=\frac{\left(e^{r_{a}}-1\right)-N I M}{\left(e^{r_{l}}-1\right)}
$$

or finally:

$$
\sigma=1-\frac{(1-l)\left[\left(e^{r_{a}}-1\right)-N I M\right]}{\left(e^{r_{l}}-1\right)}
$$

Therefore, the solvency ratio is a positive function of rate of return on earning assets and net interest margin, but inversely related to the cost rate and liquidity ratio. Since net interest margin is already determined the same way by rate of return on earning assets and cost rate, it can be concluded that the solvency ratio is directly related to net interest margin (the "bread and butter" of bank profitability) and inversely related to the liquidity ratio.

Surprisingly, solvency is inversely related to liquidity. This comes from assumption (4), "no external funds are aquired in the period." Otherwise, a bank with a low liquidity ratio (inadequate cash or cash-like holdings) will be more sensitive to funds withdrawal (or bank run), that in the worst case may compromise even bank solvency. Namely, liquidity problems may often turn into solvency problems. For example, a continuous liquidity shortage could lead a bank to sell its longer-term assets at "fire sale" prices, and decrease asset value and net worth. In that case liquidity goes hand in hand with solvency. However, in this model the link between solvency and liquidity is derived solely from the influence of liquidity ratio on profitability. Since a higher liquidity ratio means a lower proportion of earning assets to total assets, it will cause lower profitability and lower solvency, ceteris paribus.

\subsection{Stochastic framework}

So far a deterministic framework has been assumed with rates of return and cost rates expressed by their means. In order to be more realistic the rates have to be expressed as stochastic variables. If normality is accepted as an atribute of its statistical distribution then the following holds (cf. Briys et al. 1998, p. 34):

$$
r_{a, l} \approx f\left[\left(\mu-\frac{1}{2} \sigma^{2}\right)(T-t), \sigma \sqrt{T-t}\right]
$$

The expresion above (19) means that continuously compounded rates have normal distribution with mean $\mu$ and an annual standard deviation $\sigma$. Since the variable is normally distributed, a range of posible outcomes are the positive function of time span $(T-t)$. Distribution of the stohastic variable depends on its mean, standard deviation and time span. The variability of the rates is at least as equally important for expected profitability and solvency as the mean of the rates. Being, by definition, normally distributed, rate of return and cost rate have variability proportional to time span. This atribute implies that audit trials have to be as frequent as possible so that 
at any time the actual level of the variable will not depart too much from its mean.

The importance of variability is accepted by regulatory bodies (e.g. US FRS or FDIC). They regulary collect data and oversee both the mean and standard deviation of rates of return on assets and net interest margins. For instance, over a 15 year period (from 1985 thorugh 2000 for all reporting US banks), the typical US commercial bank had an average return on assets of 0.88 percent with a standard deviation of 0.38 percent compared to an average net interest margin of 3.64 percent with a standard deviation of 0.18 percent (cf. Sinkey, 2002, Table $8-2$, p. 223). The data show that the net interest margin is substantially less variable than the rate of return on assets.

\section{How the model fits current regulatory practices}

The current practices of bank supervision implemented worldwide differ in many aspects but hold some common atributes: they all are based on a system that has to be uniformly implemented. The data are compared to peer group averages and the bank's own trends. All the approaches are concerned with the bank's overall condition or the bank's default probability (i.e. downside risk) and differ mostly in their methods of computation. Some are off-site or on-site rating systems, some are statistical models for predicting failure, or rating downgrade. In recent years the improvement of supervising technology has brought new approaches, e.g. comprehensive risk assessment systems. Data for feeding analytic tools comes from balance sheets, and are in the form of various ratios, growth rates, as well as in the form of market available data and even "soft data," or the subjective assessment of management ability, internal control systems and the organizational capacity of the supervised institution.

How important earnings are in evaluating the various aspects of bank safety can be judged by their presence in various supervisory approaches implemented worldwide (Annex, tables 1-5). In 15 out of the total of 17 systems comprehensively reviewed by Sahajwala and Van den Bergh (2000) at least one indicator, proxy or profitability ratio is included. The importance of expected profitability is even bigger when adding various asset quality variables related to profitability. The list of profitability indicators, proxies or ratios includes:

a) profitability ratios: return on assets; b) income items: net income; income before taxes and extraordinary provisions; earnings before interest and taxes/total assets divided by interest on liabilities/total liabilities; operating income; quality of earnings;

c) Revenue and expences items: material components of income and expenses,

d) Asset quality and expected loss items: Non-accrual loans; loans past due (different delays); non-recurring items; loan loss reserve; gross charge-offs and provision for loan losses; adequacy of provisions for loan losses;

e) other: dividend payout ratio in relation to the adequacy of bank capital;

The issue of the desirable fraquency of reporting in the current international practice of bank supervision depends on the system's main focus: whether it is a regular rating, or following the distressed bank to screen its probability of failure or survival, or probability of being downgraded. It is within the range of annual to quarterly reporting, and clearly has become more recently shortterm oriented.

\section{Conclusions}

This simple model has several implications on the design of banking regulations: i) profitability has to be treated as "marginal" solvency, ii) a profitable bank can operate sustainably even with a low level of equity capital; iii) the supervisory framework has to be able to recognize any measure of earnings level, its trends, stability and quality; and finally iv) frequency of audit trials has to be as high as possible.

The model indicates that profitability goes hand in hand with solvency, such that a positive return is conditio sine qua non for a bank to stay on track. The above conclusions may look somehow too strong for reality. The latest financial crisis demonstrated that for most banks the years of racket profits eventually resulted in financial distress. However, this was not so much due to rapid changes in the economic environment, but rather because a high return was calculated on the basis of overoptimistic predictions.

Biased reports on assets value can certainly undermine the relevance of indicators related to profitability for regulatory purposes. Various flaws in bank reports and misrepresentations of return could be just the consequence of obliviousness or the reluctance to admit 
how likely is that the best scenario can turn into the worst. Information issues related to the market (economic) value of assets, asset quality measures, and loan loss provisions are equally harmful to calculations of both the real value of return and real value of equity. Therefore, in the real world the difference between the book value of return and equity and their real values are likely to come from the same source of inaccuracy. However, the difference itself does not compromise the model. It simply means that the model better fits reality if the variables represent real values than possibly flawed book values. ㅁ.

\section{References:}

Angbazo, L. 1997. Commercial bank net interest margins, default risk, interest-rate risk, and off-balance sheet banking, Journal of Banking and Finance 21: 55-87.

Federal Reserve Banks of San Francisco, 1999. Using CAMELS Ratings to monitor bank conditions, Economic Letter, 19, June 11.

Sahajwala, R., and Van den Bergh, P. 2000. Supervisory risk assessment and early warning systems, Working Paper No. 4, Basel Committee on Banking Supervision, Basel, December.

Sinkey, F.J., Jr. 2002. Commercial Bank Financial Management in the
Financial-Services Industry, 6th ed. Prentice Hall (NJ).

Krstić, B. 1996. Tržišni oblici kapitalizacije banaka, Ekonomske teme I-VI, 55-66.

Stigum, M., and Branch, R. 1983. Managing Bank Assets and Liabilities, Dow Jones-Irwin, Homewood (II).

Ćirović, M. 1995. Bankarski menadžment, Ekonomski institut, Beograd.

Rajan, R., and Zingales, L. 1995. What do we know about capital structure? Some evidence from international data, Journal of Finance, 50 (5): 1421-1460.

Jović, S. 1990. Bankarstvo, Naučna knjiga, Beograd.

Briys, E., Bellalah, M., Mai, H.M., and de Varenne, F. 1998. Options, futures and exotic derivatives: theory, application and practice, John Wiley and Sons, Chichester (UK).

Myers, S. 2003. Still searching for optimal capital structure, in Stern, J. M., and Chew, D. H. Jr. (eds.) The revolution in corporate finance, Blackwell Publishing.

Myers, S. 1984. The capital structure puzzle, Journal of Finance 39 (3): 575-592.

Myers, S. and Majluf, N. 1984. Corporate financing and investment decisions when firms have information that investors do not have, Journal of Financial Economics 13: 187-221.

Matten, C. 1996. Managing bank capital: capital allocation and performance measurement, John Wiley and Sons, Chichester (UK).

Merton, R., and Perold, A. 1993. Theory of risk capital in financial firms, Journal of Applied Corporate Finance, Fall, 16-30.

\section{Annex}

\section{System/category}

CAMELS (Capital, Asset Quality, Management, Earnings, Liquidity and Sensitivity to market risks) on-site examination rating

CAEL $^{1)}$ (Capital, Asset Quality, Earnings and Liquidity) - off-site

PATROL - off-site

ORAP (Organization and Reinforcement of Preventive Action) - off-site

\section{Agency}

Federal Reserve System, Federal Deposit Insurance Corporation and Office of the Comptroller of the Currency (US)

Federal Deposit Insurance Corporation (US)

Bank of Italy

Banking Commission (France)

\section{Profitability/earnings varijables}

Return on assets compared to peer group averages and bank's own trends, material components and income and expences, comparison to peers and bank's own trends, adequacy of provisions for loan losses, quality of earnings, dividend payout ratio in relation to the adequacy of bank capital.

Identical to CAMELS

One ratio for profitability and one for asset quality, out of a total of 5 indicators.

Operating income, non-recurring items and return on assets, plus four for asset quality, out of a totalof 6 indicator categories.

Notes: ${ }^{1)}$ withdrown December 1999.

Table 1: Supervisory bank rating systems

Source: Suhajwala and Van den Bergh (2000, Table 1. and Annex 1-5). 


\begin{tabular}{lll}
\multicolumn{1}{c}{ System/category } & \multicolumn{1}{c}{ Agency } & \multicolumn{1}{c}{ Profitability/earnings varijables } \\
\hline $\begin{array}{l}\text { SEER rating (System for Estimating } \\
\text { Exam Ratings) - Rating estimation }\end{array}$ & Federal Reserve System & (US) \\
$\begin{array}{ll}\text { SCOR (Statistical CAMELS Off-site } \\
\begin{array}{l}\text { Rating) - Rating downgrade } \\
\text { estimation }\end{array}\end{array}$ & $\begin{array}{l}\text { Federal Deposit } \\
\text { Insurance Corporation }\end{array}$ & $\begin{array}{l}\text { Income before taxes and extraordinary provisions; Loan loss } \\
\text { reserve, gross charge-offs and provision for loan losses plus }\end{array}$ \\
\hline
\end{tabular}

Table 2: Statistical models (Early warning rating/rating downgrade estimation)

Source: Suhajwala and Van den Bergh (2000, Table 1. and Annex 1-5).

\begin{tabular}{lll}
\multicolumn{1}{c}{ System/category } & \multicolumn{1}{c}{ Agency } & \multicolumn{1}{c}{ Profitability/earnings varijables } \\
\hline $\begin{array}{l}\text { Individual Bank Monitoring } \\
\text { Screens }\end{array}$ & $\begin{array}{l}\text { Federal Reserve System } \\
\text { (US) }\end{array}$ & $\begin{array}{l}5 \text { profitability ratios plus } 21 \text { asset quality ratios out of a total of } \\
74 \text { financial and capital market ratios }\end{array}$ \\
$\begin{array}{ll}\text { BAKIS (BAKred Information } \\
\text { System) }\end{array}$ & $\begin{array}{l}\text { German Federal } \\
\text { Supervisory Office }\end{array}$ & $\begin{array}{l}10 \text { profitability ratios plus } 18 \text { asset quality ratios out of a total of } \\
47 \text { financial and capital market ratios }\end{array}$ \\
Observation systems & Netherlands Bank & 13 profitability ratios plus 12 asset quality ratios out of a total of \\
\hline
\end{tabular}

Notes: ${ }^{2)}$ not in use yet/planned

Table 3: Financial ratio and peer group analysis systems

Source: Suhajwala and Van den Bergh (2000, Table 1. and Annex 1-5).

\begin{tabular}{lll}
\multicolumn{1}{c}{ System/category } & \multicolumn{1}{c}{ Agency } & \multicolumn{1}{c}{ Profitability/earnings varijables } \\
\hline RAST (Risk Analysis Support Tool) & Netherlands Bank & No; one for asset quality out of a total of 13 risk categories \\
$\begin{array}{l}\text { RATE (Risk Assessment, Tools of } \\
\text { Supervision and Evaluation) }\end{array}$ & $\begin{array}{l}\text { Financial Services } \\
\text { Authority (UK) }\end{array}$ & $\begin{array}{l}\text { One for profitability plus one for asset quality out of a total of } 9 \\
\text { risk categories }\end{array}$ \\
\hline
\end{tabular}

Table 4: Comprehensive bank risk assessment systems

Source: Suhajwala and Van den Bergh (2000, Table 1. and Annex 1-5).

\begin{tabular}{|c|c|c|}
\hline System/category & Agency & Profitability/earnings variables \\
\hline $\begin{array}{l}\text { SAABA (Support System for } \\
\text { Banking Analysis) - expected loss }\end{array}$ & $\begin{array}{l}\text { Banking Commission } \\
\text { (France) }\end{array}$ & $\begin{array}{l}\text { One for profitability and one for asset quality out of a total of } 5 \\
\text { ratios/categories. }\end{array}$ \\
\hline $\begin{array}{l}\text { SEER risk rank (System for } \\
\text { Estimating Exam Ratings) - } \\
\text { failure prediction }\end{array}$ & $\begin{array}{l}\text { Federal Reserve System } \\
\text { (US) }\end{array}$ & $\begin{array}{l}\text { Return on average assets and } 7 \text { for asset quality out of a total of } \\
11 \text { ratios. }\end{array}$ \\
\hline $\begin{array}{l}\text { GMS (Growth Monitoring } \\
\text { System) -tracking high growth } \\
\text { banks }\end{array}$ & $\begin{array}{l}\text { Federal Deposit Insurance } \\
\text { Corporation (US) }\end{array}$ & $\begin{array}{l}\text { None for profitability and } 6 \text { for asset quality out of a total of } 9 \\
\text { ratios/rates. }\end{array}$ \\
\hline $\begin{array}{l}\text { Bank Calculator }{ }^{3)} \text { - failure } \\
\text { prediction }\end{array}$ & $\begin{array}{l}\text { Office of the Comptroller } \\
\text { of the Currency (US) }\end{array}$ & $\begin{array}{l}\text { Earnings before interest and taxes/total assets divided by } \\
\text { interest on liabilities/total liabilities, out of a total of } 10 \\
\text { indicators. }\end{array}$ \\
\hline
\end{tabular}

Notes: ${ }^{3)}$ not in use yet/planned.

Table 5: Statistical models (early warning for failure, survival or fragility)

Source: Suhajwala and Van den Bergh (2000, Table 1. and Annex 1-5). 